\title{
Factors associated with loss of handgrip strength in long-lived elderly*
}

\author{
FATORES ASSOCIADOS À DIMINUIÇÃO DE FORÇA DE PREENSÃO MANUAL EM \\ IDOSOS LONGEVOS
}

\section{FACTORES ASOCIADOS CON LA REDUCCIÓN DE LA FUERZA DE AGARRE MANUAL EN ANCIANOS LONGEVOS}

\section{Maria Helena Lenardt' ${ }^{1}$, Clóris Regina Blanski Grden², Jacy Aurélia Vieira de Sousa ${ }^{2}$, Péricles Martim Reche ${ }^{3}$, Susanne Elero Betiolli², Dâmarys Kohlbeck de Melo Neu Ribeiro²}

\begin{abstract}
Objective: To investigate the prevalence of reduced grip strength and associated factors in long-lived elderly, who are users of primary health care. Method: Cross-sectional quantitative study, data were collected during the period of January to December of 2013, by applying tests and questionnaires. The convenience sampling was comprised of 157 seniors. Results: The findings indicate that the reduction in grip strength presents a moderate prevalence (25.5\%), predominantly among females $(19.1 \%)$, in the age group of $80-89$ years $(18.5 \%)$ and in those with lower educational levels (15.9\%). The association between reduced grip strength and the variables of age and body mass index showed a statistical significance. Conclusion: Investigations about the handgrip strength are essential for identifying clinical conditions of Brazilian long-lived elderly, and contribute to the development of plans towards the management of frailty.
\end{abstract}

\section{DESCRIPTORS}

Frail elderly

Hand strength

Geriatric nursing

Health of the elderly

\section{RESUMO}

Objetivo: Investigar a prevalência da redução da força de preensão manual e fatores associados em idosos longevos, usuários da atenção básica de saúde. Método: Estudo quantitativo transversal, cujos dados foram coletados no período de janeiro a dezembro de 2013, por meio de testes e aplicação de questionários. A amostra por conveniência compreendeu 157 idosos. Resultados: Apontam que a redução da força de preensão manual possui prevalência moderada $(25,5 \%)$, com predomínio do sexo feminino $(19,1 \%)$, da faixa etária de 80 a 89 anos (18,5\%) e baixa escolaridade $(15,9 \%)$. A associação entre diminuição da força de preensão manual e as variáveis idade e índice de massa corpórea mostrou significância estatística. Conclusão: As investigações sobre o componente da força de preensão manual são fundamentais para a identificação das condições clínicas dos idosos longevos brasileiros e contribuem para a construção de planos voltados para a gestão da fragilidade.

\author{
DESCRITORES \\ Idoso fragilizado \\ Força da mão \\ Enfermagem geriátrica \\ Saúde do idoso
}

\section{RESUMEN}

Objetivo: Investigar la prevalencia de la reducción de la fuerza de agarre manual y los factores asociados en ancianos longevos, usuarios de la atención básica a la salud. Método: Estudio cuantitativo transversal, cuyos datos fueron recogidos en el período de enero a diciembre de 2013, por medio de pruebas y aplicación de cuestionarios. La muestra por conveniencia comprendió a 157 ancianos. Resultados: Señalan que la reducción de la fuerza de agarre manual tiene prevalencia moderada $(25,5 \%)$, con predominio del sexo femenino $(19,1 \%)$, del rango de edad de 80 a 89 años $(18,5 \%)$ y baja escolaridad (15,9\%). La asociación entre la disminución de la fuerza de agarre manual y las variables de edad e índice de masa corpórea mostró significación estadística. Conclusión: Las investigaciones acerca del componente de la fuerza de agarre manual son fundamentales para la identificación de las condiciones clínicas de los ancianos longevos brasileños y contribuyen para la construcción de planes dirigidos a la gestión de la fragilidad.

\section{DESCRIPTORES \\ Anciano frágil \\ Fuerza de la mano \\ Enfermería geriátrica \\ Salud del anciano}

\footnotetext{
* Extracted from the research project entitled "Efeitos da fragilidade em idosos longevos da comunidade", Federal University of Paraná; $2012 .{ }^{1}$ Senior Professor, Graduate Program in Nursing, Federal University of Paraná, Curitiba, PR, Brazil. ${ }^{2}$ Doctorate Student, Graduate Program in Nursing, Federal University of Paraná, Curitiba, PR, Brazil. ${ }^{3}$ Assistant Professor, State University of Ponta Grossa, Ponta Grossa, PR, Brazil.

$1 \begin{aligned} & \begin{array}{r}\text { Rev Esc Enferm USP } \\ 2014 ; 48(6): 1004-10 \\ \text { www.ee.usp.br/reeusp/ }\end{array} \text { Received: 07/17/2014 } \\ & \text { Approved: 09/18/2014 }\end{aligned}$
}




\section{INTRODUCTION}

Life expectancy for those aged 80 or more, also called longevity, has been increasing every decade. According to a survey by the Brazilian Institute of Geography and Statistics (IBGE), there are three million people in this age group in Brazil(1). Despite the high prevalence of physical frailty in this age group due to the relationship of this syndrome with biological aging, not every elderly will necessarily become vulnerable ${ }^{(2)}$, a fact that indicates the need for this screening for this condition, especially among the long-lived.

In recent decades, the term frailty has been highlighted in studies of aging. The various theoretical and operational definitions are controversial ${ }^{(3-4)}$. However, in 2012, a group of representatives of six significant international corporations and experts in the field agreed on important aspects of the syndrome, although there is no final consensus as of yet. Thus, physical frailty became characterized as a medical syndrome with multiple causes and contributions, which is characterized by reduced strength and endurance, and reduced physiological function that increases the vulnerability of the individual and leads to the development of greater dependence and / or death ${ }^{(3)}$.

This condition is based on a tripod of alterations related to senescence: neuromuscular disorders, dysregulation of the neuroendocrine system, and immune system dysfunction. These changes, when associated with a physiological cycle of exacerbated decline of multiple systems, can lead the elderly to a state of vulnerability ${ }^{(5)}$.

The phenotype of physical frailty is composed of markers for evaluation and elderly characterization, which are: slow gait, reduced grip strength, unintentional weight loss, exhaustion, low self-reported physical activity level(5-6). Elderly individuals without evidence of markers are not considered frail, those with one or two are called pre-fragile, and those presenting three or more markers are characterized as frail.

Among these components, we have elected the Handgrip Strength (HGS) as the study object, which is used in research as an indicator of the body's muscle strength and an important marker of frailty ${ }^{(7)}$. It is considered as a predictor of disability, morbidity and mortality ${ }^{(8-9)}$, and studies indicate its association with age, as people aged $\geq$ 80 are more likely to present HGS loss, and a correlation between decreased muscle mass and strength ${ }^{(9-10)}$.

The reduction of the strength of the dominant hand in frail elders can undermine the performance of manual tasks and is associated with other important functional limitations in gait and balance, with significant consequences, such as increased risk of falls and loss of functional independence ${ }^{(11)}$. Thus, assessing grip strength is a useful test as part of the clinical evaluation in order to determine the risk of accelerated decline in the elderly health ${ }^{(12)}$.
Given the above, the objective of this study was to investigate the prevalence of reduced handgrip strength and associated factors in the long-lived elderly who are users of primary health care services.

\section{METHOD}

A cross-sectional quantitative study was conducted in two Basic Health Units (BHU) in Curitiba (PR). The target population consisted of those aged $\geq 80$ years who were waiting for medical consultation at the BHUs. Data collection was conducted from January to December of 2013, and the convenience sample was comprised of 157 longlived elderly. Inclusion criteria were: aged $\geq 80$ years old; being registered in any of the health clinics included in the research; and, presenting a higher score than the cutoff value in the application of the Mini Mental State Examination (MMSE), with the cutoff of 13 points for illiterates, 18 for medium and low educational levels, and 26 points for high educational level ${ }^{(13-14)}$.

Individuals with previous diagnoses of serious mental illness or severe mental deficits that might hinder their participation in the study, those residents in long-term care institutions, and those receiving chemotherapy treatment were excluded. For those with limited verbal communication, or who did not attain the cutoff value, we invited the family caregiver to participate in the interview, in order to respond to questions related to demographic and clinical issues, with the exception of the tests that were conducted with the elderly. Inclusion criteria for the caregiver were the following: aged $\geq 18$ years of age, role of familiar caregiver, living with the elderly for at least three months. The exclusion criterion was the desire to withdraw consent for study participation.

For data collection we applied a social, demographic and clinical questionnaire, and a test for HGS assessment. Sociodemographic variables were: gender, age, marital status, with whom they lived, educational level, and economic status. Clinical variables included: selfreported diseases, number of hospitalizations, history of falls in the last 12 months, urinary incontinence, medication use, and body mass index (BMI). For clinical assessment we included the following variables: feeling lonely, use of assistive technologies (walking cane, walker, crutch, corrective lenses), smoking and alcohol consumption habits, understanding that these variables influence health of the elderly and how they live, and thus were significant for the study.

The body mass index (BMI), in $\mathrm{kg} / \mathrm{m} 2$, was calculated from the following anthropometric measurements: height in meters, measured with the use of an inelastic and flexible measure tape with $0.1 \mathrm{~cm}$ precision; weight in kilograms, measured by using a portable digital scale with a capacity of up to $150 \mathrm{~kg}$ and a $100 \mathrm{~g}$ precision. The cutoff 
points established for seniors were: $\mathrm{BMI} \leq 22 \mathrm{~kg} / \mathrm{m}^{2}$ (underweight); $22 \mathrm{~kg} / \mathrm{m}^{2}<\mathrm{BMl}<27 \mathrm{~kg} / \mathrm{m}^{2}$ (normal weight); $\mathrm{BMI} \geq 27 \mathrm{~kg} / \mathrm{m}^{2}$ (overweight) ${ }^{(15)}$.

The Handgrip Strength (HGS) test was conducted in the simultaneous presence of two examiners, with a hydraulic dynamometer in kilograms/force (kgf), manufactured under the Jamar brand, following the recommendation of the American Society of Hand Therapists $(\mathrm{ASHT})^{(16)}$. The elderly sat with his/her feet touching the ground; the upper limb under examination was positioned with the shoulder adducted, the elbow flexed to $90^{\circ}$ and the forearm in neutral position. The grip was set for the elderly individual's dominant hand, so that the second phalanx of the second, third and fourth fingers touched the curve of the device stem. Participants performed three grips with the dominant hand, with a oneminute interval between them to allow the strength to return, and the higher measure was observed ${ }^{(8)}$. After adjustment for gender, the values of the lowest quintile were considered to have HGS reduction ${ }^{(6)}$.

Data were tabulated and analyzed using Stata 12 software, and were described by measures of frequency, mean and standard deviation (SD). The association between the variables was analyzed with the chi-square and Fisher tests, using the significance level of $5 \%(p=0.05)$ for results interpretation.

The development of the study met the national and international ethical standards in research involving humans. The Ethics Committee on Human Research of the Division of Health Sciences approved it, under the CAAE registration number 07993712.8.0000.0102.

\section{RESULTS}

Of the 157 long-lived elderly, 40 (25.5\%) presented reduced grip strength; most of them were women $(\mathrm{n}=$ $30 ; 28.8 \%)$, aged $80-89$ years ( $n=29 ; 21 \%)$, minimum age of 80 years and maximum age of 95 years (mean age of $84.8 ; \pm 2.9)$. The age variable was significant for low HGS $(p=0.001)$ (Table 1$)$.

Among those woman aged 80 years and above, the lowest and highest HGS values were of 8 and $38 \mathrm{kgf}$, respectively, with a medium value of $17.9 \mathrm{kgf}$. For males, the lower grip strength was $15 \mathrm{kgf}$ and the highest was $48 \mathrm{kgf}$, with a medium value of $29.11 \mathrm{kgf}$. The value of HGS corresponding to the lowest quintile identified in the sample was $14 \mathrm{kgf}$ for women and 23.6 for men, corresponding to a reduced HGS.

Regarding marital status, 30 (30.6\%) were widowed, and $23(25.8 \%)$ lived with relatives. As for the educational level, $25(25.8 \%)$ of the elderly had not finished elementary school. Eighteen $(27.7 \%)$ rated their economic status as median (Table 1 ).
Table 1 - Distribution (\%) of the long-lived elderly according to social and demographic characteristics and grip strength - Curitiba, PR, Brazil, 2013

\begin{tabular}{|c|c|c|c|c|}
\hline $\begin{array}{l}\text { Classification/ } \\
\text { Variables }\end{array}$ & $\begin{array}{c}\text { Reduced } \\
\text { HGS* } \\
\text { n (\%) }\end{array}$ & $\begin{array}{c}\text { Normal } \\
\text { HGS* } \\
\text { n (\%) }\end{array}$ & $\begin{array}{l}\text { Total } \\
\text { n (\%) }\end{array}$ & p-value $\dagger$ \\
\hline \multicolumn{5}{|l|}{ Gender } \\
\hline Male & $10(18.9)$ & $43(81.1)$ & $53(33.8)$ & 0.175 \\
\hline Female & $30(28.8)$ & $74(71.2)$ & $104(66.2)$ & \\
\hline \multicolumn{5}{|l|}{ Age } \\
\hline $80-89$ years & $29(21)$ & $109(79)$ & $138(88)$ & $0.001 \dagger$ \\
\hline 90 - 99 years & $11(57.9)$ & $08(42.1)$ & $19(12)$ & \\
\hline \multicolumn{5}{|l|}{ Civil status } \\
\hline Married & $8(15.7)$ & $43(84.3)$ & $51(32.4)$ & 0.113 \\
\hline Widowed & $30(30.6)$ & $68(69.4)$ & $98(62.4)$ & \\
\hline Single & $02(25)$ & $06(75)$ & $8(5.2)$ & \\
\hline \multicolumn{5}{|l|}{ Who they live with } \\
\hline Relatives & $23(25.8)$ & $66(74.2)$ & $89(56.6)$ & 0.686 \\
\hline Alone & $12(28.6)$ & $30(71.4)$ & $42(26.7)$ & \\
\hline Partner/Spouse & $05(20)$ & $20(80)$ & $25(16.7)$ & \\
\hline \multicolumn{5}{|l|}{ Schooling } \\
\hline Illiterate & $12(24.5)$ & $37(75.5)$ & $49(31.2)$ & 0.848 \\
\hline $\begin{array}{l}\text { Incomplete elementary } \\
\text { school }\end{array}$ & $25(25.8)$ & $72(74.2)$ & $97(61.7)$ & \\
\hline $\begin{array}{l}\text { Completed elementary } \\
\text { school }\end{array}$ & $01(16.7)$ & $05(83.3)$ & $6(3.8)$ & \\
\hline Incomplete high school & $0(0)$ & $0(0)$ & $0(0)$ & \\
\hline Completed high school & $2(40)$ & $3(60)$ & $5(3,3)$ & \\
\hline Higher education & $0(0)$ & $0(0)$ & $0(0)$ & \\
\hline \multicolumn{5}{|l|}{ Financial status } \\
\hline Average & $18(27.7)$ & $47(72.3)$ & $65(41.4)$ & 0.842 \\
\hline Satisfactory & $16(24.6)$ & $49(75.4)$ & $65(41.4)$ & \\
\hline Unsatisfactory & $6(22.2)$ & $21(77.8)$ & $27(17.2)$ & \\
\hline Total & $40(25.5)$ & $117(74.5)$ & $157(100)$ & \\
\hline
\end{tabular}

In Table 2, we observe a significant number of long-lived elderly who reported health problems $(n=39 ; 25.5 \%)$ and who were under medication therapy $(n=37 ; 25 \%)$ among those who had reduced HGS; however, the majority 29 (23.6\%) had not been hospitalized in the last 12 months.

Of the respondents, 21 (25.6\%) reported no falls in the last 12 months, 27 (27.5\%) did not feel lonely, 20 $(26.7 \%)$ had no urinary incontinence, 39 (25.5\%) were non-smokers, and 37 (25.5\%) did not drink alcohol. Regarding the use of assistive technologies, $30(23.3 \%)$ reported not using a walking cane or walker $(n=38 ; 24.8 \%)$ or crutches ( $n=39 ; 25 \%)$. The use of corrective lenses was reported by $24(24 \%)$. It is noteworthy that $15(20 \%)$ had a normal BMI. There was an association between reduction of HGS and BMI consistent with normal weight $(p=0.002)$ (Table 2). 
Table 2 - Distribution (\%) of the long-lived elderly according to self-reported clinical conditions and grip strength - Curitiba, PR, Brazil, 2013

\begin{tabular}{|c|c|c|c|c|}
\hline Classification/Variables & Reduced HGS* n (\%) & Normal HGS* n (\%) & Total n (\%) & p value $\dagger$ \\
\hline \multicolumn{5}{|l|}{ Self-reported diseases } \\
\hline Yes & $39(25.5)$ & $114(74.5)$ & 153(97.4) & 0.982 \\
\hline No & $01(25)$ & $3(75)$ & $4(2.6)$ & \\
\hline \multicolumn{5}{|c|}{$\begin{array}{l}\text { Hospitalizations in the past } 12 \\
\text { months }\end{array}$} \\
\hline Yes & $11(32.3)$ & $23(67.7)$ & $34(21.6)$ & 0.299 \\
\hline No & $29(23.6)$ & $94(76.4)$ & $123(78.4)$ & \\
\hline \multicolumn{5}{|l|}{ Medication therapy } \\
\hline Yes & $37(25)$ & $111(75)$ & $148(94.3)$ & 0.694 \\
\hline No & $03(33.3)$ & $06(66.7)$ & $09(5.7)$ & \\
\hline \multicolumn{5}{|c|}{ Falls in the past 12 months } \\
\hline Yes & $19(25.3)$ & $56(74.7)$ & $75(47.8)$ & 0.968 \\
\hline No & $21(25.6)$ & $61(74.4)$ & $82(52.2)$ & \\
\hline \multicolumn{5}{|l|}{ Feeling lonely } \\
\hline Yes & $13(22.4)$ & $45(77.6)$ & $58(37)$ & 0.566 \\
\hline No & $27(27.5)$ & $72(73.5)$ & $98(63)$ & \\
\hline \multicolumn{5}{|l|}{ Urinary incontinence } \\
\hline Yes & $20(26.7)$ & $55(73.3)$ & $75(47.7)$ & 0.744 \\
\hline No & $20(24.4)$ & $62(75.6)$ & $82(52.3)$ & \\
\hline \multicolumn{5}{|l|}{ Smoking habit } \\
\hline Yes & $01(25)$ & $03(75)$ & $04(2.6)$ & 0.982 \\
\hline No & $39(25.5)$ & $114(74.5)$ & $153(97.4)$ & \\
\hline \multicolumn{5}{|l|}{ Alcohol consumption } \\
\hline Yes & $03(25)$ & $09(75)$ & $12(7.6)$ & 0.968 \\
\hline No & $37(25.5)$ & $108(74.5)$ & $145(92.4)$ & \\
\hline \multicolumn{5}{|l|}{ Use of walking cane } \\
\hline Yes & $10(35.7)$ & $18(64.3)$ & $28(17.9)$ & 0.170 \\
\hline No & $30(23.3)$ & $99(76.7)$ & $129(82.1)$ & \\
\hline \multicolumn{5}{|l|}{ Use of walker } \\
\hline Yes & $02(50)$ & $02(50)$ & $04(2.8)$ & 0.254 \\
\hline No & $38(24.8)$ & $115(75.2)$ & 153(97.2) & \\
\hline \multicolumn{5}{|l|}{ Use of crutches } \\
\hline Yes & $01(100)$ & $0(0)$ & $01(0.64)$ & 0.255 \\
\hline No & $39(25)$ & $117(75)$ & $156(99.36)$ & \\
\hline \multicolumn{5}{|l|}{ Corrective lenses } \\
\hline Yes & $24(24)$ & $76(76)$ & $100(63.7)$ & 0.574 \\
\hline No & $16(28.1)$ & 41(71.9) & $57(36.3)$ & \\
\hline \multicolumn{5}{|l|}{ Body Mass Index } \\
\hline Low weight & $13(54.2)$ & $11(45.8)$ & $24(15.3)$ & $0.002^{\dagger}$ \\
\hline Normal weight & $15(20)$ & $60(80)$ & $75(47.8)$ & \\
\hline Overweight & $12(20.7)$ & $46(79.3)$ & $58(36.9)$ & \\
\hline Total & $40(25.5)$ & $117(74.5)$ & $157(100)$ & \\
\hline
\end{tabular}

Note: results expressed by frequency (percentage).

*HGS= Handgrip Strength

${ }^{*}$ Chi- square, $p<0.05$

\section{DISCUSSION}

Most women had reduced grip strength ( $n=30 ; 28.8 \%)$, a fact that can be attributed to the age group, especially when it comes to women $>80$ years of age. Studies have shown a significant association between reduced grip strength and female gender $r^{(9,17)}$.
The mean value of HGS of the long-lived elderly was significantly higher among males $(29.1 \pm 10.5 \mathrm{kgf})$ when compared to females (17.9 $\pm 4.9 \mathrm{kgf})$, corroborating the findings found in the literature ${ }^{(9)}$, which can be explained by the fact that men have higher reserves of muscle mass than women ${ }^{(18)}$.

The age group with the largest number of seniors was between $80-89$ years. However, $57.9 \%$ of 
participants aged between 90 - 94 years showed a HGS reduction, i.e., showed three times more frequency of HGS reduction than the rest of the participants aged $>$ 80 years. Studies corroborate this data, indicating that the higher the age, the greater the likelihood of HGS reduction $(p=0.001)^{(10,19)}$.

Most of the participants presenting reduced HGS were widowed $(n=30 ; 30.6 \%)$. Similar results were observed in a study conducted in the Netherlands(12), that aimed to evaluate HGS as predictive of changes in functional, psychological and social health of the elderly. Among the long-lived elderly, widowhood can contribute to social and family isolation, therefore leading to the development of self-care deficit, caused by the lack of encouragement of the partner. On the other hand, paternalistic attitudes of the partner or family can compromise the independence and autonomy of older people.

Regarding education, the majority of the elderly with reduced grip strength had incomplete primary education $(n=25 ; 25.8 \%)$, which may be due to lack of access to the educational system observed in past generations. In this study, there was no significant association between educational level and reduction of HGS. However, researchers affirm that low educational level is a crucial factor to the decline of grip strength among the elderly ${ }^{(20)}$.

In regard to financial status, $27.7 \%$ of participants reported it as average. A study conducted with 27,351 participants of the Survey of Health, Ageing and Retirement in Europe identified an association between financial status in elderly and grip strength ${ }^{(21)}$, suggesting that older adults with good economic condition have lower rates of disease and mortality, i.e., the favorable economic situation eases barriers in relation to functional impairment ${ }^{(6,10,20)}$.

The majority of the long-lived elderly with reduced HGS had health problems. Diseases can trigger the cycle of frailty in the elderly ${ }^{(6)}$, and this shows that recommendations aimed at preventing health problems are strongly indicated, particularly for the elderly without HGS alterations.

Similarly, the majority of participants reported that they were under medication therapy. International studies conducted with the elderly have shown an association between HGS and reduced consumption of certain classes of medications such as psychotropic ${ }^{(22)}$ and cardiovascular medicines ${ }^{(23)}$, noting that this practice, when excessive or inappropriate, may generate a negative impact on functional capacity, specially in the HGS among the elderly ${ }^{(24)}$.

Regarding the occurrence of falls, the findings are divergent from the current literature, since most of those aged $>80$ years with reduced $\mathrm{HGS}$ reported no falls in the past one year. The literature presents studies showing a significant association between reduced grip strength and higher incidence of falls $s^{(17,25)}$. In this study, this finding may be due to a sample of participants who had the ability to walk to the BHU, which possibly contributed to the exclusion of individuals who have suffered falls in the past 12 months.

Half of the long-lived elderly reported having urinary incontinence. This geriatric syndrome was significantly associated with grip strength in other studies ${ }^{(26-27)}$, which reinforces the decrease in factors related to functional capacity, such as HGS, and may be associated with dependency in activities of daily living in the elderly, regardless of age.

A BMI consistent with normal weight was significantly associated to the reduction of handgrip strength. Similar results were observed in a cross-sectional study conducted in Campina Grande with 420 seniors, which had as its aim to verify the correlation of handgrip strength and flexibility with age and anthropometric measures. The findings showed that there was a significant correlation between $\mathrm{BMI}$ and the reduction of HGS, however, only among females ${ }^{(9)}$.

International studies ${ }^{(6,28)}$ point out that the progressive reduction in the muscle mass of the elderly is related to physical disability, mobility and mortality. The authors of these studies recommend that health professionals should identify functional and muscular disorders among the elderly, especially those who are long-lived, as they can predict frail and pre-frail status.

\section{CONCLUSION}

The prevalence of reduced grip strength was moderate (25.5\%) in the long-lived study participants, users of primary health care services. This condition was associated with age and $\mathrm{BMI}$.

We highlight as a limitation of the study the convenience sample composed of those long-lived elderly who were able to go to BHUs, which possibly contributed to the non-inclusion of individuals with reduced handgrip strength. It is suggested that a study conducted with older seniors should include home visits as a strategy for data collection, to cover those with lower functional performance and who cannot attend a health facility

The hydraulic dynamometer, an instrument for handgrip strength measurement is not something commonly seen at BHUs, which complicates the evaluation of this component in the primary health care setting. Although this academic research has no immediate intention of leading to the evaluation of grip strength in professional practice, it is believed that this implementation is possible in primary care settings.

Investigations on the Frailty Syndrome and its assessment components are essential to the identification of the clinical conditions of Brazilian long-lived elderly, as well as to raise subsidies for their care in the management of physical frailty.
Factors associated with loss of handgrip strength in long-lived elderly Lenardt MH, Grden CRB, Sousa JAV, Reche PM, BetiolliSE, Ribeiro DKMN 


\section{REFERENCES}

1. Instituto Brasileiro de Geografia e Estatística. Síntese de Indicadores Sociais. Uma análise das condições de vida da população brasileira [Internet]. Rio de Janeiro: IBGE; 2012 [citado 2013 ago. 10]. Disponível em: ftp://ftp.ibge.gov.br/Indicadores_Sociais/Sintese_de_Indicadores_Sociais_2012/SIS_2012.pdf

2. Neri AL. Fragilidade e qualidade de vida na velhice. Campinas: Alínea; 2013. Fragilidade e qualidade de vida na velhice; p.16-29.

3. Morley JE, Vellas B, Kan GAV, Anker SD, Bauer JM, Bernabei R, et al. Frailty consensus: a call to action. J Am Med Dir Assoc. 2013;14(6):392-7.

4. Lacas A, Rockwood K. Frailty in primary care: a review of its conceptualization and implications for practice. BMC Med. 2012;10:4.

5. Fried L, Tangen CM, Walston J, Newman AB, Hirsch C, Gottdiener J, et al. Frailty in older adults: evidence for a phenotype. J Gerontol A Biol Sci Med Sci. 2001;56(3):M146-56.

6. Fried L, Ferrucci L, Darer J, Williamson JD, Anderson G. Untangling the concepts of disability, frailty and comorbidity: implications for improved targeting and care. J Gerontol A Biol Sci Med Sci. 2004;59(3):255-63.

7. Xue QL. The frailty syndrome: definition and natural history. Clin Geriatr Med. 2011;27(1):1-15.

8. Geraldes AAR, Oliveira ARM, Albuquerque RB, Carvalho JM, Farinatti PTV. A força de preensão manual é boa preditora do desempenho funcional de idosos frágeis: um estudo correlacional múltiplo. Rev Bras Med Esporte. 2008;14(1):12-6.

9. Silva NA, Menezes TN, Melo TLP, Pedraza DF. Força de preensão manual e flexibilidade e suas relações com variáveis antropométricas em idosos. Rev Assoc Med Bras. 2013;59(2):128-35.

10. Ribeiro LHM, Neri AL. Exercícios físicos, força muscular e atividades de vida diária em mulheres idosas. Ciênc Saúde Coletiva. 2012;17(8):2169-80.

11. Pereira R, Cardoso BS, Itaborahy AS, Machado M. Análise da força de preensão de mulheres idosas: estudo comparativo entre faixas etárias. Acta Med Port. 2011;24(4):521-6.

12. Taekema DG, Gussekloo J, Maier AB, Westendorp RG, Craen AJ. Handgrip strength as a predictor of functional, psychological and social health. A prospective population-based study among the oldest old. Age Ageing. 2010;39(3):331-7.

13. Folstein MF, Folstein SE, McHugh PR. "Mini-mental state": a practical method for grading the cognitive state of patients for the clinician. J Psychiatr Res. 1975;12(3):189-98.
14. Bertolucci PH, Brucki SM, Campacci SR, Juliano Y. O Miniexame do estado mental em uma população geral: impacto da escolaridade. Arq Neuropsiquiatr. 1994;52(1):1-7.

15. Brasil. Ministério da Saúde. Orientações para a coleta e análise de dados antropométricos em serviços de saúde: norma técnica do Sistema de Vigilância Alimentar e Nutricional (SISVAN). Brasília; 2011.

16. Bohannon RW, Peolsson A, Massy-Westropp N, Desrosiers J, Bear-Lehman J. Reference values for adult grip strength measured with a Jamar dynamometer: a descriptive metaanalysis. Physiotherapy. 2006;92(1):11-5.

17. Cheung $\mathrm{CL}$, Tan $\mathrm{K}$, Bow $\mathrm{CH}$, Soong CSS, Loong $\mathrm{CHN}$, Kung AWC. Low hand grip streng this a predictor of osteoporotic fractures: cross-sectional and prospective evidence from the Hong Kong Osteoporsis Study. Age (Dordr). 2012;34(5):1239-48.

18. Auyeung TW, Lee SWJ, Leung J, Kwok T, Woo J. Age-associated decline of muscle mass, grip strength hand gait speed: $A$ 4-year longitudinal study of 3018 community-dwelling older Chinese. Geriatr Gerontol Int. 2014;14(1):76-84.

19. Reis Filho AD, Santini E, Neves T, Fett WCR, Fett CA. Análise do estado nutricional e da força de preensão palmar, lombar e escapular em mulheres de meia idade e idosas. Braz J Biomotr. 2012;6(4):245-53.

20. Quan S, Jeong JY, Kim DH. The relationship between smoking, socioeconomic status and grip strength among community-dwelling elderly men in Korea: Hallym Aging Study. Epidemiol Health [Internet]. 2013 [cited 2013 Aug 10];35:e201 3001. Available from: http://www.ncbi.nlm.nih. gov/pmc/articles/PMC3575580/

21. Hairi FM, Mackenbach JP, Andersen-Ranberg K, Avendano $M$. Does socio-economic status predict grip strength in older Europeans? Results from the SHARE study in non-institutionalised men and women aged 50+. J Epidemiol Commmunity Health. 2010;64(9):829-37.

22. Galik E, Resnick B. Psychotropic medication use and association with physical and psychosocial outcomes in nursing home residents. J Psychiatr Ment Health Nurs. 2013;20(3):244-52.

23. Ashfield TA, Syddall HE, Martin HJ, Dennison EM, Cooper C, Sayer AA. Grip strength and cardiovascular drug use in older people: findings from the Hertfordshire Cohort Study. Age Ageing. 2010;39(2):185-91.

24. Jensen LD, Hallin M, Andersen O, Petersen J. Is weakness in older patients caused by inappropriate drug use? Eur J Hosp Pharm 2013;20 Suppl 1:A39. 
25. Rodrigues WKM, Rocha SV, Barros NA, Santos CA. Fatores associados ao declínio da força muscular em membros superiores entre idosos residentes em áreas rurais. Arq Ciênc Esporte. 2013;1(1):14-20.

26. Kim H, Yoshida H, Hu X, Saito K, Yoshida Y, Kim M, et al. Association between self-reported urinary incontinence and musculoskeletal conditions in community-dwelling elderly women: a cross-sectional study. Neurourol Urodyn. 2014 Jan 28. [Epub ahead of print]
27. Seino S, Yabushita N, Kim MJ, Nemoto M, Jung S, Osuka Y, et al. Physical performance measures as a useful indicator of multiple geriatric syndromes in women aged 75 years and older. Geriatr Gerontol Int. 2013;13(4):901-10.

28. Walston J, Hadley EC, Ferrucci L, Guralnik JM, Newman $A B$, Studenski $S A$, et al. Research agenda for frailty in older adults: toward a better understanding of physiology and etiology: summary from the American Geriatrics Society/ National Institute on Aging Research Conference on Frailty in Older Adults. J Am Geriatr Soc. 2006;54(6):991-1001.

\section{Financial support:}

Araucária Foundation, Senior Scholarship Program 